\title{
Real-Time, Continuous Water-Quality Monitoring in Indiana and Kentucky
}

Water-quality "super" gages (also known as "sentry" gages) provide real-time, continuous measurements of the physical and chemical characteristics of stream water at or near selected U.S. Geological Survey (USGS) streamgages in Indiana and Kentucky. A super gage includes streamflow and water-quality instrumentation and representative stream sample collection for laboratory analysis. USGS scientists can use statistical surrogate models to relate instrument values to analyzed chemical concentrations at a super gage. Real-time, continuous and laboratory-analyzed concentration and load data are publicly accessible on USGS Web pages.

\section{How Does a Water-Quality Super Gage Operate?}

A continuous water-quality gage (known as a super or sentry gage) uses in-stream instruments to measure streamflow, water-quality characteristics, nitrate, and phosphate many times a day and throughout the year. Traditional, intermittent water samples can miss changes in water quality that happen at night, during storms, and when it is not practical or affordable for a sample team to operate. A statistical model can be used to combine continuous and intermittent watersample data at super gages so that constituent concentrations and loads (such as pounds per day) can be continuously computed. The operation of a super gage has the following components:

- Measurement of stream stage and streamflow. An instrument continuously measures stream stage (also known as gage height), which is related to routine measurements of stream velocity in order to compute instantaneous streamflow (also known as stream discharge) in cubic feet per second. Understanding flow conditions and how physical and chemical characteristics of stream water respond to flow changes are important to increasing overall understanding of stream-water quality. For example, some water-quality characteristics and concentrations increase due to overland runoff during high streamflow conditions, while others can decrease or be diluted during high streamflow.

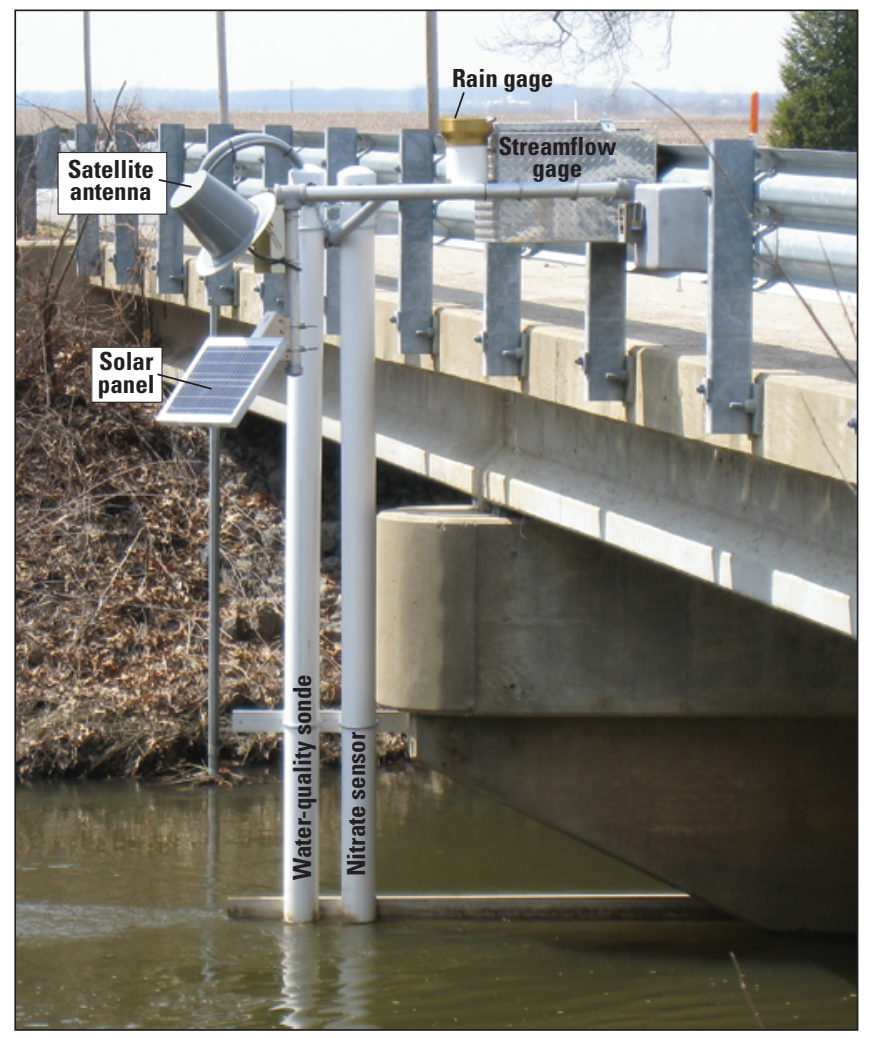

U.S. Geological Survey super gage, Kankakee River at Davis, Indiana, which measures, records, and transmits continuous water-quality characteristics.
- Measurement of water-quality characteristics and nutrients. An in-stream water-quality sonde can continuously measure turbidity, dissolved oxygen, specific conductance, $\mathrm{pH}$, and water temperature every 15 minutes; however, time intervals between recorded values can be as short as 5 minutes. Some super gages include an ultravioletabsorbance sensor used to measure nitrogen concentration in the form of nitrate plus nitrite, and (or) a chemical-reaction light-absorbance analyzer used to measure phosphate. Table 1 lists instrument reporting limits. An on-site data logger stores measurements and satellite telemetry transmits the data hourly to publicly accessible USGS Web pages.

- Routine quality control. USGS field teams routinely visit super gages to clean and check calibration of in-stream instruments. Measurement drift due to biofouling is quantified, while independent meters and standard solutions of known concentration are used to verify the accuracy of the
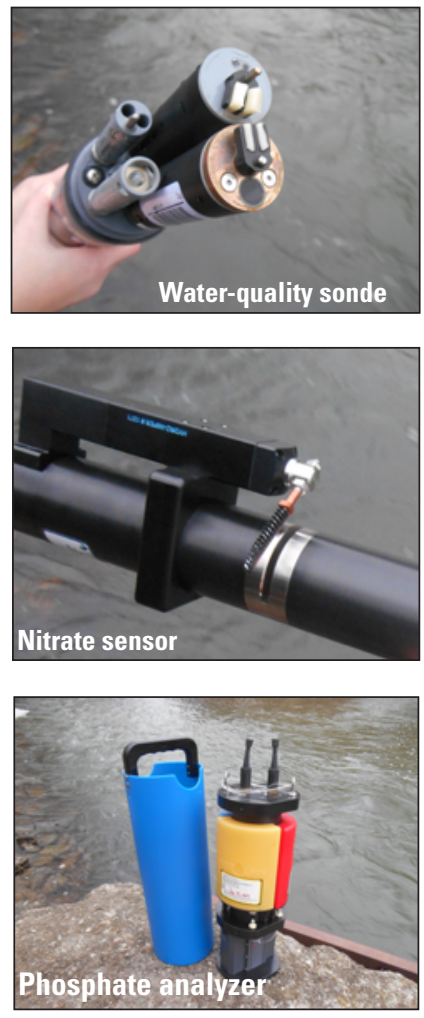

Immersible instruments used to measure water quality at U.S. Geological Survey super (sentry) gages. in-stream instruments. For quality control, mathematical corrections are applied to selected data, if needed. Standard USGS procedures are documented in Pellerin and others (2013), Wagner and others (2006), and the National Field Manual (U.S. Geological Survey, variously dated).

- Representative stream samples. Stream width- and depthintegrated samples are routinely collected at a super gage, and the samples are analyzed at a laboratory for physical or chemical characteristics (parameters) listed in table 1. Concentrations such as nitrate and phosphate are used for comparison with the in-stream sensor and analyzer, respectively

- Statistical surrogate models. Concentrations from laboratory analysis and corresponding values from in-stream instruments are combined to develop a statistical surrogate model for characteristics of stream water that are not easy to continuously measure. The model computes real-time concentrations based on continuous in-stream sensor readings of another, more easily measured value. Turbidity is commonly used as a surrogate for suspended-sediment concentration. Daily, monthly, and annual loads can be computed and compared to understand seasonal and annual variability. 
Table 1. Water-quality parameters for analysis of U.S. Geological Survey water samples at a super gage.

[FNU, Formazin nephelometric units; mg/L, milligrams per liter; $\mu \mathrm{S} / \mathrm{cm}$, microsiemens per centimeter at 25 degrees Celsius; su, standard units; ${ }^{\circ} \mathrm{C}$, degrees Celsius]

\begin{tabular}{|c|c|c|c|c|}
\hline Parameters & $\begin{array}{l}\text { Reporting } \\
\text { limit }\end{array}$ & Units & $\begin{array}{l}\text { Determi- } \\
\text { nation }\end{array}$ & Method \\
\hline Turbidity & 0.1 & FNU & sensor & optical \\
\hline Dissolved oxygen & 0.01 & $\mathrm{mg} / \mathrm{L}$ & sensor & optical \\
\hline $\begin{array}{l}\text { Specific } \\
\text { conductance }\end{array}$ & 1 & $\mu \mathrm{S} / \mathrm{cm}$ & sensor & electrical \\
\hline $\mathrm{pH}$ & 0.1 & $\mathrm{su}$ & sensor & electrode \\
\hline Water temperature & 0.1 & ${ }^{\circ} \mathrm{C}$ & sensor & thermistor \\
\hline Nitrate plus nitrite & 0.01 & $\mathrm{mg} / \mathrm{L}$ & sensor & optical \\
\hline Dissolved phosphate & 0.008 & $\mathrm{mg} / \mathrm{L}$ & analyzer & colorimetry \\
\hline $\begin{array}{l}\text { Suspended sediment, } \\
\text { sand-fine break }\end{array}$ & 1 & $\mathrm{mg} / \mathrm{L}$ & laboratory & filtration \\
\hline $\begin{array}{l}\text { Dissolved ammonia } \\
\text { nitrogen }\end{array}$ & 0.01 & $\mathrm{mg} / \mathrm{L}$ & laboratory & colorimetry \\
\hline $\begin{array}{l}\text { Dissolved nitrite } \\
\text { nitrogen }\end{array}$ & 0.001 & $\mathrm{mg} / \mathrm{L}$ & laboratory & colorimetry \\
\hline $\begin{array}{l}\text { Dissolved nitrite and } \\
\text { nitrate nitrogen }\end{array}$ & 0.04 & $\mathrm{mg} / \mathrm{L}$ & laboratory & $\begin{array}{l}\text { alkaline } \\
\text { persulfate }\end{array}$ \\
\hline $\begin{array}{l}\text { Total nitrogen*, } \\
\text { unfiltered }\end{array}$ & 0.05 & $\mathrm{mg} / \mathrm{L}$ & laboratory & colorimetry \\
\hline $\begin{array}{l}\text { Dissolved } \\
\text { orthophosphate } \\
\text { phosphorous }\end{array}$ & 0.004 & $\mathrm{mg} / \mathrm{L}$ & laboratory & colorimetry \\
\hline $\begin{array}{r}\text { Phosphorus, } \\
\text { unfiltered }\end{array}$ & 0.004 & $\mathrm{mg} / \mathrm{L}$ & laboratory & colorimetry \\
\hline
\end{tabular}

*Includes ammonia, nitrite, nitrate, and organic nitrogen.

\section{Nitrate Monitoring of the Lower Green River, Kentucky}

The Lower Green River Basin is a highly agricultural area in Kentucky that was selected as a priority basin for the Mississippi River Basin Healthy Watersheds Initiative (MRBI) led by the Natural Resources Conservation Service (Natural Resources Conservation Service, 2008). The goal of the MRBI is to improve water quality while maintaining agricultural productivity. Since 2013, the USGS, in cooperation with the Kentucky Governor's Office of Agricultural Policy, has been measuring continuous nitrate concentrations and computing nitrate loads discharged from the Lower Green River to the Ohio River, a major tributary to the Mississippi River. These data are critical for evaluating the effectiveness of agriculturalnutrient management plans and strategies implemented in the basin.

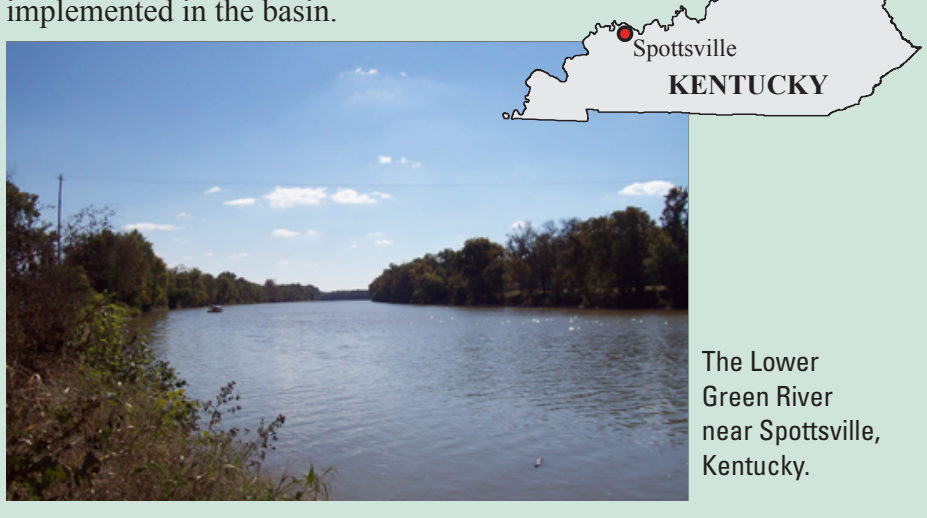

\section{Demonstration of Super Gage on Eagle Creek in Zionsville, Indiana}

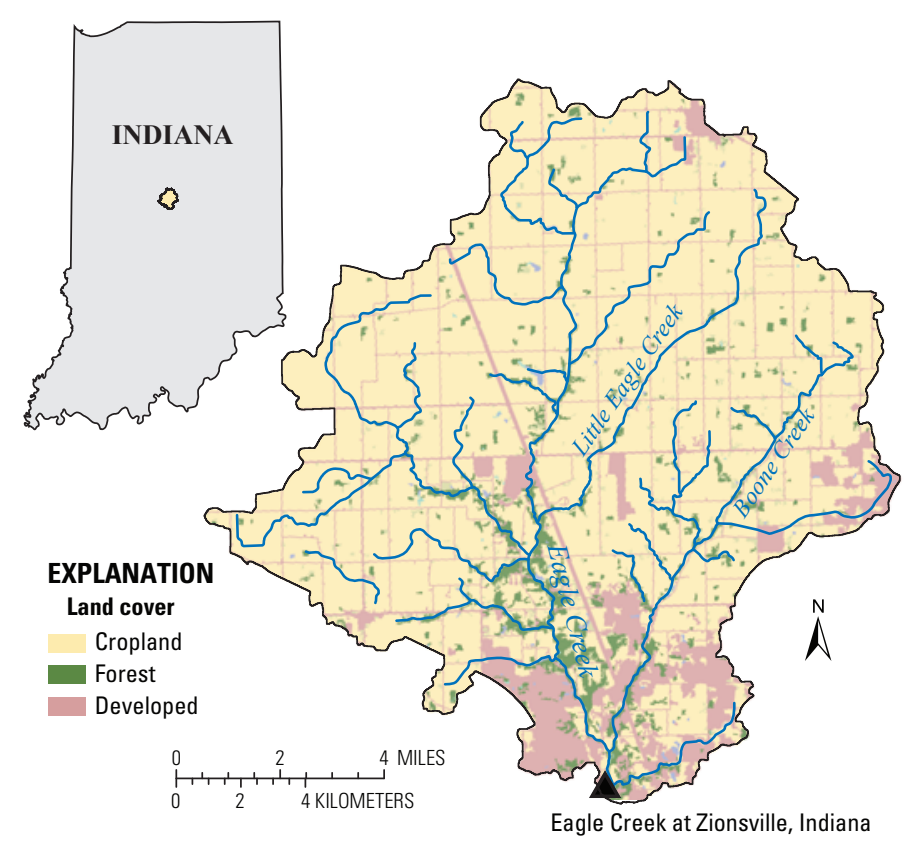

Eagle Creek flows through the town of Zionsville, Indiana, in southeast Boone County, north of Indianapolis. The USGS has operated a super gage on Eagle Creek since 2010 as a demonstration and test site. Water-quality instruments, a weather station, soil-moisture probes, and a remote video camera have been used to showcase the wide variety of real-time, continuous data that can be served at a super gage. The site also has been used by USGS to test different types of water-quality instruments such as nitrate sensors and analyzers. Eagle Creek at Zionsville is an important super gage for understanding the effects of land use on water quality. Since 2000, the town has more than tripled in size and the watershed is transitioning from agricultural to suburban land use. Eagle Creek is the major tributary to Eagle Creek Reservoir, a water source for the Indianapolis public water supply that experiences episodic algal blooms from possible nutrient enrichment.

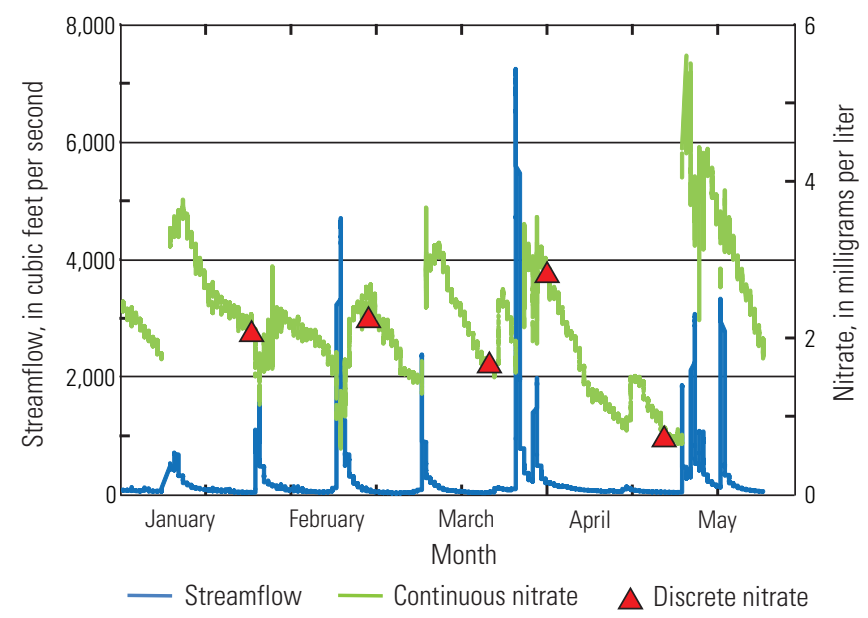

Continuous streamflow and nitrate concentrations measured at the super gage on Eagle Creek at Zionsville, Indiana, in 2014. Continuous nitrate concentrations respond to changes in streamflow. These responses in nitrate may not be detected with discrete samples alone. 


\section{Sediment and Nutrient Monitoring of the Kankakee River, Indiana}

The Kankakee River Basin in northwestern Indiana drains 2,989 square miles and includes the Kankakee River and Iroquois River, which flow into the Illinois River west of the Indiana-Illinois border. The Kankakee River Basin Commission (KRBC) coordinates management activities for flood control, recreation, water quality, and soil conservation in Indiana (Kankakee River Basin Commission, 2014). The Grand Kankakee Marsh was drained in the past century, and the Kankakee River and many of its tributaries were channelized to promote drainage for agricultural land.

Since 2012, the USGS, in cooperation with the KRBC, has measured continuous turbidity and stream discharge at three super gages to understand the concentrations and loads of suspended sediment transported in the Yellow River, a major tributary of the Kankakee River (see map). Statistical surrogate models were developed to relate continuous turbidity measurements to analyzed concentrations of suspended sediment sampled at these gages. An example comparing the changes in turbidity at the three gages on the Yellow River is shown (see graphs).

As of 2015, the USGS operates two other super gages in the Kankakee Basin - the Kankakee River at Davis, Ind. (05515500), and the Iroquois River at Foresman, Ind. (05524500) (see map). These super gages continuously monitor water-quality characteristics, nitrate concentrations, and streamflow to document changes in response to land-management practices.

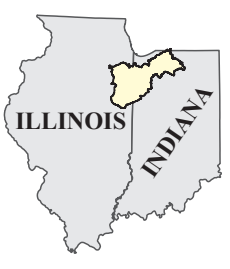

\section{EXPLANATION}

\section{Gage type}

Sentry

O Sediment

- Streamflow

$\triangle$ Stream stage

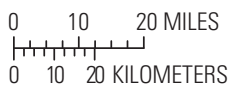

$0 \quad 10 \quad 20$ KILOMETERS
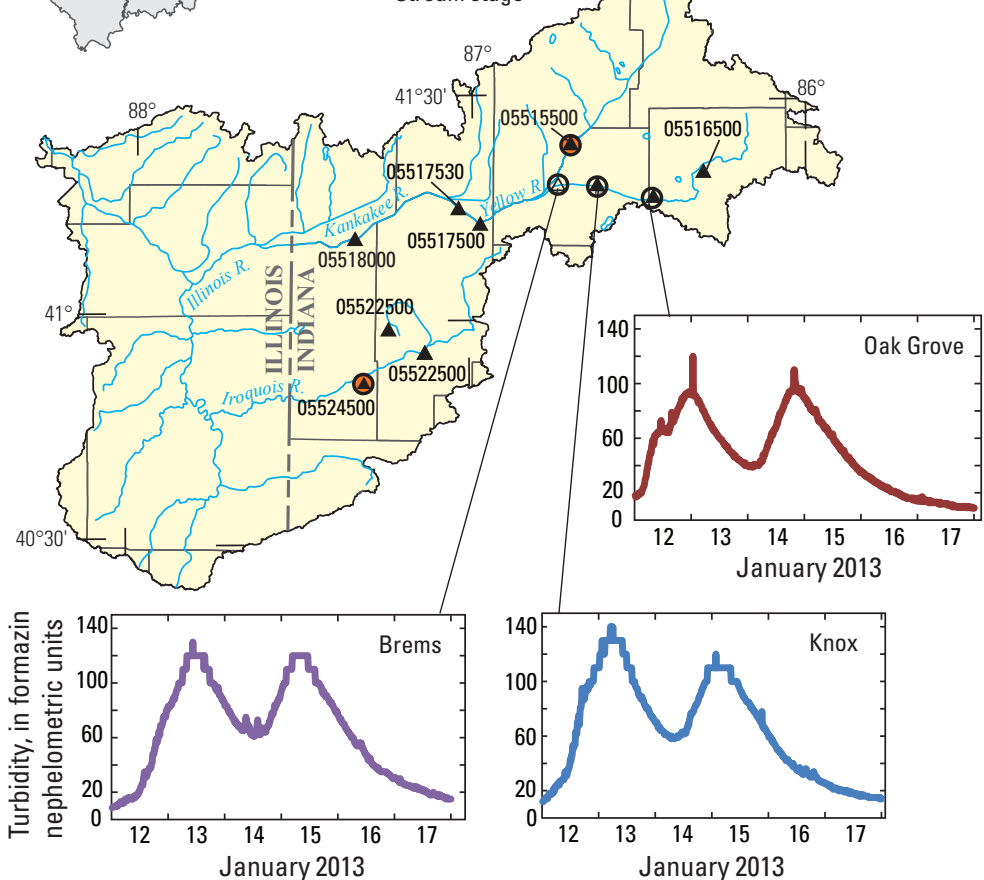

Effects of storm runoff and high streamflow on turbidity for three super gages in the Yellow River watershed, Indiana. The greatest increase in turbidity occurs between the sites Oak Grove and Knox, Ind., and high levels persist downstream to the site near Brems, Ind.

\section{Statistical Surrogate Models to Compute Constituent Concentrations and Loads}

Most parameters in table 1 also are commonly termed "constituents." Concentrations of water-quality constituents in routine water samples are determined by laboratory analysis. The resulting laboratory analyzed concentrations are then compared to surrogate values measured by continuous in-stream instruments at concurrent times. USGS scientists develop and refine statistical regression models between constituent concentrations and surrogate values for a range of streamflow and constituent conditions. Once a regression model is developed, the in-stream continuous sensor values act as a surrogate to compute continuous constituent concentrations. As an example, turbidity, the clarity of water in a stream, is often used as a surrogate for suspended sediment (see graph). The relation between suspended sediment and turbidity is site specific, but is usually consistent and definable (Rasmussen and others, 2009). Surrogate models, as described above, can be developed for various constituents including in-stream nitrate sensor data as a surrogate for total nitrogen, in-stream phosphate analyzer data for total phosphorus, or turbidity and streamflow data combined for total phosphorus.

At super gages, instantaneous constituent loads are computed as the product of the concentrations and streamflow (see graph), typically every 15 minutes. Daily, monthly, and annual summary loads can be computed in pounds per day or tons per year. Watershed yields are computed by dividing summary loads by drainage area, which results in measurements of pounds per square mile per year.
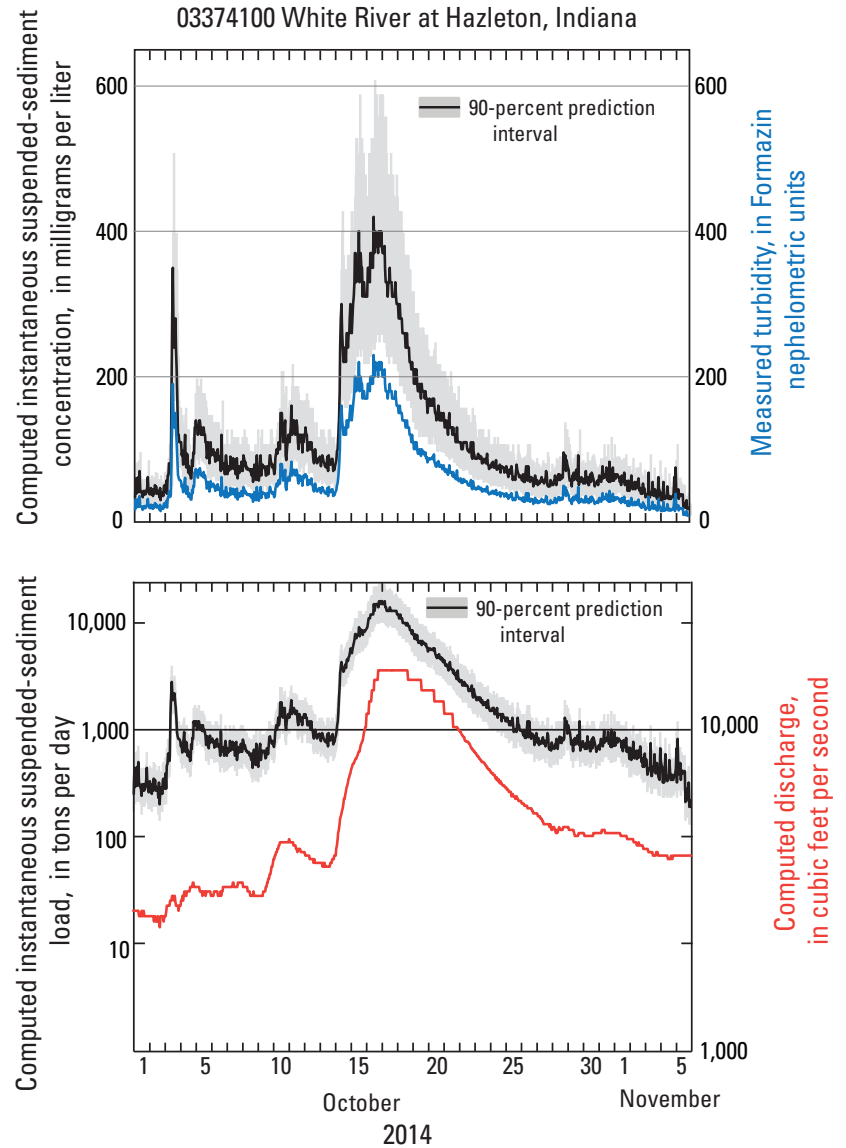


\section{How to Access Data}

USGS continuous water-quality data and models are located on the USGS National Real-Time Water Quality Web site, http://nrtwq.usgs.gov. The Web site features

- Interactive maps of States with real-time, continuous waterquality monitoring gages, with lists of the constituents measured and links to the data for each gage.

- Links to maps of States with gages that have surrogate models to predict constituent concentrations that are not measured directly with in-stream instruments.

- Links to published methods used to develop surrogate models through statistical regression and site specific information.

- Surrogate model data available as plots or tables, with the 90-percent confidence interval for calculated values.

\section{Quality Control}

The USGS uses quality-control protocols to insure that data are accurate, representative of stream conditions, reproducible, and consistently collected.

- A USGS scientist visits each super gage regularly to clean and, if necessary, recalibrate water-quality sensors according to USGS-approved methods. Information collected during site visits is used to quality assure the continuous data record and to provide a data-quality rating for each time period.

- Daily review of the real-time data for each super gage determines that instruments are operating correctly and that malfunctions are resolved promptly.

- Representative water-quality samples and cross-stream water-quality profiles are used to verify that super gage instruments are accurately portraying in stream conditions.

- Surrogate models are developed following USGS guidelines (Rasmussen and others, 2009) and undergo a thorough review process.
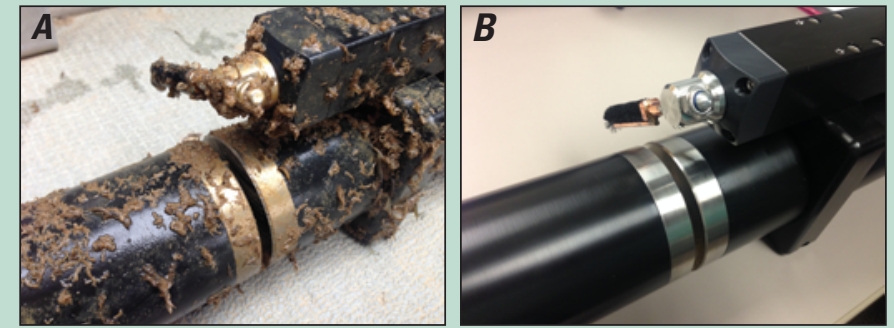

Two in-stream nitrate sensors. $A$, Dirty sensor. $B$, Clean sensor. Biofouling of in-stream nitrate sensors is managed by regular cleaning and inspection.

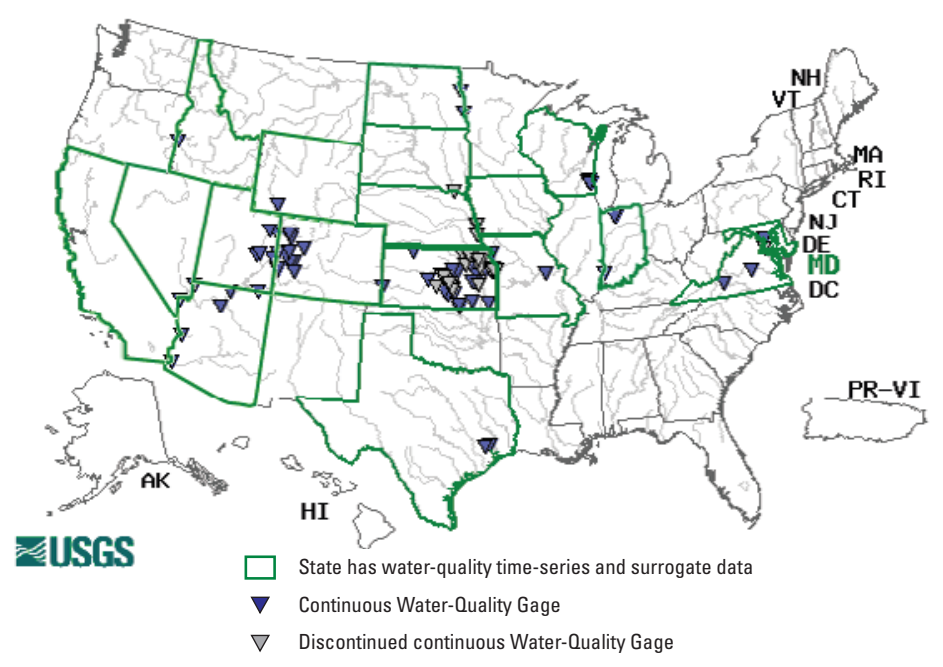

The U.S. Geological Survey water-quality sentry gages in Indiana and Kentucky are part of a national network.

\section{References Cited}

Kankakee River Basin Commission, 2014, About the Kankakee River Basin Commission, accessed March 12, 2015, at http://www.kankakeeriverbasin.org/about.html.

Natural Resources Conservation Service, 2008, Farm Bill 2008 fact sheet: Mississippi River Basin Healthy Watersheds Initiative (MRBI), http://www.nrcs.usda.gov/Internet/FSE_DOCUMENTS/ nrcs142p2_009290.pdf.

Pellerin, B.A., Bergamaschi, B.A., Downing, B.D., Saraceno, J.F., Garrett, J.D., and Olsen, L.D., 2013, Optical techniques for the determination of nitrate in environmental waters: Guidelines for instrument selection, operation, deployment, maintenance, qualityassurance, and data reporting: U.S. Geological Survey Techniques and Methods book 1, chap. D5, 37 p., available at http://pubs.er.usgs. gov/publication/tm1D5.

Rasmussen, P.P., Gray, J.R., Glysson, G.D., and Ziegler, A.C., 2009, Guidelines and procedures for computing time-series suspended-sediment concentrations and loads from in-stream turbidity-sensor and streamflow data: U.S. Geological Survey Techniques and Methods book 3, chap. C4, 53 p., available at http://pubs.er.usgs.gov/publication/tm3C4.

U.S. Geological Survey, variously dated, National field manual for the collection of water-quality data: U.S. Geological Survey Techniques of Water-Resources Investigations, book 9, chaps. A1-A9, available online at http://pubs.water.usgs.gov/twri9A.

Wagner, R.J., Boulger, R.W., Jr., Oblinger, C.J., and Smith, B.A., 2006, Guidelines and standard procedures for continuous water-quality monitors - Station operation, record computation, and data reporting: U.S. Geological Survey Techniques and Methods book 1, chap. D3, 51 p., plus 8 attachments, available at http://pubs.water.usgs.gov/ tm1d3.

\section{For Additional Information}

Visit the Indiana-Kentucky Water Science Center

(http://in.water.usgs.gov/super_gages/)

Indianapolis office: 317-290-3333 (http://in.water.usgs.gov/)

Louisville office: 502-493-1900 (http://ky.water.usgs.gov/)

\section{Authors:}

Megan E. Shoda, Timothy R. Lathrop, and Martin R. Risch

ISSN 2327-6916 (print)

ISSN 2327-6932 (online)

http://dx.doi.org/10.3133/fs20153041 